\title{
Knowing, Unknowing, Believing stances and characters' dialogic identities in the Harry Potter books
}

\author{
Laura Dorigato, Gill Philip, Ramona Bongelli and \\ Andrzej Zuczkowski \\ University of Macerata, Italy
}

In a previous paper (Philip et al. 2013) we presented the analysis of the main characters' identities, as they emerge from the dialogues in Chapter 10 of the seventh book of the Harry Potter series, in relation to their Knowing, Unknowing, and Believing epistemic stances. The aim of the present study is to expand this analysis to all seven books of the same saga, in particular focusing on how Harry and Lord Voldemort negotiate, construct, and develop their identities and how they evolve in what they know, believe, and do not know through the dialogues in the seven books. This study also aims to compare this linguistic analysis to a literary one. The results show that the epistemic roles in the dialogues support the characters' identities in the narrative.

Keywords: Harry Potter, dialogic identity, epistemic position, literary critics

\section{Knowing, Unknowing, and Believing positions}

In a previous paper (Philip et al. 2013) we analyzed the dialogues of the main characters in Chapter 10 of the seventh book of the Harry Potter saga (Harry, Ron, and Hermione, plus Kreacher), in relation to their Knowing, Unknowing, and Believing (KUB) epistemic positions. ${ }^{1}$ Within the framework of the KUB model, dialogic communication can be viewed as an exchange of information originating in one of these three epistemic positions and directed towards another (Bongelli et al. 2013; Philip et al. 2013; Riccioni et al. 2013; Zuczkowski et al. 2014). To sum up the concepts defined in detail in those previous studies, the Knowing position is the one

1. In the present contribution, Known, Unknown, Believed and other categories used in the analysis are capitalised to distinguish them from normal discursive uses of the words. 
assumed by the speaker/writer when s/he communicates (lexically and/or morphosyntactically) the information as Known to him/her: e.g., "It's five o'clock".

When the speaker/writer assumes an Unknowing position, s/he communicates the information (lexically and/or morphosyntactically) as Unknown to him/ her, i.e., as neither certain or uncertain: e.g., "I don't know what time it is", "What time is it?".

The Believing position is assumed by the speaker/writer when s/he communicates the information (lexically and/or morphosyntactically) as believed (supposed, hypothesized, etc.) to him/her, i.e., as uncertain: e.g. "Perhaps it's five o'clock", "I think it's five o'clock".

The main difference between the three positions is that in the first the speaker/ writer (says that $\mathrm{s} / \mathrm{he}$ ) knows the information $\mathrm{p}$, in the second $\mathrm{s} /$ he (says that $\mathrm{s} / \mathrm{he}$ ) does not know $\mathrm{p}$, in the third $\mathrm{s} /$ he (says that $\mathrm{s} / \mathrm{he}$ ) does not know whether $\mathrm{p}$ or not p. It is important to note the difference between Unknowing (not knowing) and not knowing whether (Believing): information which is communicated from an Unknowing position involves absence of knowledge (I don't know at all, I have no idea, I don't have the faintest idea) rather than the information communicated from a Believing position which is unconfirmed or uncertain (beliefs, suppositions, etc.).

In Table 1 we present the main Knowing, Unknowing and Believing markers:

Table 1. KUB lexical and morphosyntactic markers

\begin{tabular}{|c|c|c|c|}
\hline & Knowing & Unknowing & Believing \\
\hline Lexical markers & $\begin{array}{l}\text { Evidential verbs } \\
\text { (I remember...) } \\
\text { Epistemic verbal ex- } \\
\text { pressions } \\
\text { (I have no doubt...) } \\
\text { Epistemic adverbials } \\
\text { (surely...) }\end{array}$ & $\begin{array}{l}\text { Negative form of the } \\
\text { evidential verbs of the } \\
\text { Known } \\
\text { (I don't remember...) } \\
\text { Adjectives } \\
\text { (unknown...) }\end{array}$ & $\begin{array}{l}\text { Epistemic verbs } \\
\text { (I suppose...) } \\
\text { Verbal epistemic expres- } \\
\text { sions (it is possible...) } \\
\text { Epistemic adjectives and ad- } \\
\text { verbials (likely, perhaps...) } \\
\text { Modal verbs in the simple } \\
\text { present }\end{array}$ \\
\hline $\begin{array}{l}\text { Morphosyntactic } \\
\text { markers }\end{array}$ & $\begin{array}{l}\text { Clauses in the present, } \\
\text { past and future with } \\
\text { no lexical evidential or } \\
\text { epistemic marker }\end{array}$ & $\begin{array}{l}\text { "Literal" interrogatives } \\
\text { (i.e. excluding rhetori- } \\
\text { cal questions, question } \\
\text { tags, etc.) }\end{array}$ & $\begin{array}{l}\text { Modal verbs in conditional } \\
\text { and subjunctive moods } \\
\text { If clauses } \\
\text { Epistemic future }\end{array}$ \\
\hline
\end{tabular}

From an epistemic viewpoint, during an interaction, the speaker puts her/himself in a specific epistemic position and assigns to her/his interlocutor a complementary epistemic status (Heritage and Raymond 2005; Heritage 2011, 2012a, 2012b). Therefore, e.g., if a speaker asks a (plain) question to her/his interlocutor, s/he puts her/himself in an Unknowing position and assigns her/his interlocutor the 
status of being more knowledgeable. Vice versa, if a speaker puts her/himself in a Knowing position, e.g., recounting a personal event to his/her interlocutor, s/he assigns her/him the status of being less knowledgeable. There are also communicative situations in which the interlocutors provide one another with information stemming from their Believing positions.

The main aims of Philip et al. (2013) were to verify if the three KUB positions could contribute to a reading of the plot and its progression, and also to verify how aspects of the characters emerged through the language they use in their dialogic communication. This application of the KUB model to Chapter 10 confirmed and lent weight to the literary analysis of characterization.

\section{Aims and methodology}

In the present study our aims were: (i) to expand the above mentioned analysis to all the dialogues of the seven books of the same saga in order to evaluate how the main characters place themselves and develop in terms of knowledge/ absence of knowledge/ belief, according to their epistemic positions (for reasons of space, in this article we focus, as an example, only on two characters, Harry Potter and Lord Voldemort, since they are the main hero and villain and thus essential for the development of the plot), and (ii) to compare the results of our linguistic analysis to literary criticism of these books (Granger 2007, 2008; Heilman 2009; Whited 2002), in order to ascertain to what extent these two different analyses support each other.

All the parts of the seven Harry Potter books containing dialogues between Harry Potter and Lord Voldemort were extracted and analyzed, in order to display the development of each character's identity and the relationship between them, considering how it changes epistemically speaking. These dialogues were divided into clauses, whose central node is the verb, because in this way we could compare them quantitatively. Each clause was tagged as $\mathrm{K}, \mathrm{U}$, or $\mathrm{B}$, according to the Knowing, Unknowing, and Believing positions.

Other linguistic phenomena, such as Question tags, Rhetorical question tags, Rhetorical questions, Miratives and Vocatives which are in the two fragments to be analyzed in the present contribution (Sections 3.1 and 3.2) were tagged using the following labels:

QTAG to indicate a Question tag

RHET QTAG to indicate a Rhetorical question tag

RHET Q to indicate a Rhetorical question

MIRATIVE to indicate a Mirative

VOCATIVE to indicate a Vocative 
${ }^{*}$-CIT (where ${ }^{*}$ is the tag name) to indicate any clause which is a citation of another's words

In principle, Rhetorical question tags, Rhetorical questions (Blankenship and Craig 2006; Han 2002; Heinemann 2008; Jinjun 2007) and Vocatives have been considered as K, Question tags (Blankenship and Craig 2007a, 2007b; Cameron et al. 1989; Cheng 1995) as B. Miratives were left untagged because the Mirative function refers to a dynamic process occurring during the transition of a piece of information from Unknown to Known, and therefore does not (and cannot) fall within the domain of only $\mathrm{K}, \mathrm{U}$, or B. As a matter of fact, it indicates the moment in which a speaker shows his/her surprise about receiving an unexpected piece of information (DeLancey 1997, 2001; Lazard 1999, 2001; Peterson 2010, 2013). An example of Mirative from Book 1, Harry Potter and the Philosopher's Stone (Rowling 1997, 42):

\section{Hagrid: Harry, vocaTIVE | yer a wizard. KNOWN}

Harry: I'm a what? MIRATIVE

This action of tagging, i.e., labelling each clause, is straightforward in most cases; in some others it is complex, because the interpreters have to take into account not only the linguistic aspects, which are often ambiguous or polyvalent, but also the narrative context, the progression of the events, and so on. In the analysis of the two excerpts to follow (Sections 3.1 and 3.2), we made explicit the possible different readings of those clauses which permit more than one interpretation and the reasons for making our final choice.

\section{Linguistic analysis}

The clauses were entered into tables which include the turn numbers, the speakers' names, the clauses, and the tags which highlight the speakers' epistemic positions.

In order to show how we performed the linguistic analysis of the dialogues between Harry and Voldemort and to exemplify the progression of their knowledge through the seven books, we present two dialogic extracts, one from Book 2 (Harry Potter and the Chamber of Secrets), ${ }^{2}$ the other from the seventh and final one (Harry Potter and the Deathly Hallows).

2. Book 2 was chosen in preference to Harry Potter and the Philosopher's Stone because the dialogues between Harry and Voldemort are minimal and very short in the first book; the first proper dialogue between the two characters takes place in Book 2 . 


\subsection{First dialogue between Harry and Voldemort}

The first dialogue to be analysed is found in the second book, Harry Potter and the Chamber of Secrets, Chapter 17 "The Heir of Slytherin"3 (Rowling 1998, 226-233). In the dialogues between Harry and Voldemort to be found here, there is a predominance of an Unknowing position in Harry and a Knowing one in Voldemort. Figure 1 shows an extract from the tagged dialogue between these two characters:

\begin{tabular}{|c|c|c|c|}
\hline Turn & Speaker & Text & Tag \\
\hline 96 & $\mathrm{HP}$ & How did Ginny get like this? & $\mathrm{U}$ \\
\hline \multirow[t]{7}{*}{97} & $\mathrm{~V}$ & Well, that's an interesting question. & $\mathrm{K}$ \\
\hline & & And quite a long story. & $\mathrm{K}$ \\
\hline & & I suppose & $\mathrm{B}$ \\
\hline & & the real reason Ginny Weasley's like this & $\mathrm{B}$ \\
\hline & & is because & B \\
\hline & & she opened her heart & B \\
\hline & & and spilled all her secrets to an invisible stranger & B \\
\hline 98 & HP & What are you talking about? & $\mathrm{U}$ \\
\hline \multirow[t]{19}{*}{99} & $\mathrm{~V}$ & The diary. & K \\
\hline & & My diary. & $\mathrm{K}$ \\
\hline & & Little Ginny's been writing in it for months and months, & K \\
\hline & & telling me all her pitiful worries and woes: & $\mathrm{K}$ \\
\hline & & how her brothers tease her, & $\mathrm{K}$ \\
\hline & & $\begin{array}{l}\text { how she had to come to school with second-hand robes and } \\
\text { books, }\end{array}$ & $\mathrm{K}$ \\
\hline & & how-how she didn't think & $\mathrm{K}$ \\
\hline & & famous, good, great Harry Potter would ever like her... & $\mathrm{K}$ \\
\hline & & It's very boring, & K \\
\hline & & $\begin{array}{l}\text { having to listen to the silly little troubles of an eleven-year-old } \\
\text { girl.... }\end{array}$ & $\mathrm{K}$ \\
\hline & & But I was patient. & $\mathrm{K}$ \\
\hline & & I wrote back, & K \\
\hline & & I was sympathetic, & $\mathrm{K}$ \\
\hline & & I was kind. & $\mathrm{K}$ \\
\hline & & Ginny simply loved me. & $\mathrm{K}$ \\
\hline & & No one's ever understood me like you, & $*_{\text {-CIT }}$ \\
\hline & & Tom... & $*_{\text {-CIT }}$ \\
\hline & & I'm so glad & *-CIT \\
\hline & & I've got this diary & $*_{\text {-CIT }}$ \\
\hline
\end{tabular}

3. The extract shown in the table spans the central part, pages $228-229$. 


\begin{tabular}{|c|c|c|c|}
\hline Turn & Speaker & Text & Tag \\
\hline & & to confide in... & ${ }^{*}$-CIT \\
\hline & & It's like having a friend & *-CIT \\
\hline & & I can carry round in my pocket... & ${ }^{*}$-CIT \\
\hline & & If I say it myself, & $\mathrm{B}$ \\
\hline & & Harry, & VOCATIVE \\
\hline & & I've always been able to charm the people & $\mathrm{K}$ \\
\hline & & I needed. & $\mathrm{K}$ \\
\hline & & So Ginny poured out her soul to me, & $\mathrm{K}$ \\
\hline & & and her soul happened & $\mathrm{K}$ \\
\hline & & to be exactly & $\mathrm{K}$ \\
\hline & & what I wanted. & $\mathrm{K}$ \\
\hline & & $\begin{array}{l}\text { I grew stronger and stronger on a diet of her deepest fears, her } \\
\text { darkest secrets. }\end{array}$ & $\mathrm{K}$ \\
\hline & & I grew powerful, far more powerful than little Miss Weasley. & $\mathrm{K}$ \\
\hline & & $\begin{array}{l}\text { Powerful enough to start feeding Miss Weasley a few of my } \\
\text { secrets, }\end{array}$ & $\mathrm{K}$ \\
\hline & & to start pouring a little of my soul back into her... & $\mathrm{K}$ \\
\hline 100 & HP & What d'you mean? & $\mathrm{U}$ \\
\hline \multirow[t]{6}{*}{101} & $\mathrm{~V}$ & Haven't you guessed, yet, & RHET Q \\
\hline & & Harry Potter? & VOCATIVE \\
\hline & & Ginny Weasley opened the Chamber of Secrets. & $\mathrm{K}$ \\
\hline & & She strangled the school roosters & $\mathrm{K}$ \\
\hline & & and daubed threatening messages on the walls. & K \\
\hline & & $\begin{array}{l}\text { She set the serpent of Slytherin on four Mudbloods, and the } \\
\text { Squib's cat. }\end{array}$ & $\mathrm{K}$ \\
\hline
\end{tabular}

Figure 1. KUB analysis of an excerpt from Harry Potter and the Chamber of Secrets, Chapter 17, 228-229

In the extract shown in Figure 1, there are only three clauses uttered by Harry, all three tagged as U (Unknown) since Harry asks Voldemort for information which Harry does not know. Lord Voldemort's clauses, on the other hand, are far more numerous in number (in this extract we can see 43, after removing the citation from Ginny's diary in turn 99, against Harry's three), virtually all of which are tagged as K (Known), except for five clauses tagged as B (Believed) (cf. turn 97, when Voldemort makes a hypothesis about what caused Ginny's personality to change - a supposition, not a statement of fact).

In turn 101 Voldemort uses a question "Haven't you guessed, yet, Harry Potter?" to emphasize his own knowledge and Harry's ignorance. In principle, according to the KUB model, plain questions come from an Unknowing position and they are addressed to the Knowing position of the other: the speaker presumes 
that the interlocutor knows the information s/he does not. On the contrary, when questions are rhetorical, they can be tagged either B or K. In this particular case, our interpretation is to treat the question as rhetorical because Voldemort does not expect an answer: further support for this interpretation is the absence of a pause for turn-taking (an answer from Harry) - Voldemort continues speaking.

There are two other possible readings. The first can be paraphrased roughly as "I (Voldemort) expected you (Harry) to have understood, but from your question I THINK you haven't. Therefore I am asking for confirmation". This would be classed as B since it stems from a Believing position (I think...). The second alternative reading can be expressed as "I expected you to have understood, but from your question I KNOW you haven't. Therefore I am criticizing you: you haven't understood yet". This reading, in which we can trace a shade of irony and perhaps a little triumphalism in Voldemort, who knows something Harry does not, would be classed as $\mathrm{K}$ (coming from a Knowing position).

Our inclination is towards the latter reading: a Rhetorical question from a Knowing position. Voldemort's criticism is presented as a question (the sentence structure is interrogative), but the information conveyed is the corresponding declarative sentence: you haven't guessed yet.

Throughout the dialogue in Chapter 17 (pages 226-233), the predominance of Lord Voldemort's Knowing positions, compared with Harry's, and the predominance of Harry's Unknowing positions, compared with Lord Voldemort's, are evident. Table 2 summarises the tags assigned to the clauses in this extended dialogic sequence.

The raw figures in Table 2 below already give an indication of the proportions of the information types in the utterances of each of the characters, but, in order to compare the proportions more effectively, it is helpful to look at percentage figures. Figure 2 shows the same data converted into percentage values, thus facilitating direct comparison between the two characters and their preferred information types. ${ }^{4}$

The percentage-based values for information types shown in Figure 2 highlight the extent to which Voldemort's speech is dominated by Knowns (77\% of his output, or 208 clauses). He is also responsible for all of the Rhetorical questions which, considered together with Knowns as a particular way of presenting Known information, paint him as the authority in this dialogue - both in terms of knowledge itself, and deportment as a figure of authority lecturing to a subordinate. Harry is overwhelmed. Just over half his speech consists of Knowns (52\%), which is far lower a proportion than what we can consider 'normal' (the average overall here, in the second dialogue, and indeed in the dialogue analysed in Philip et al. 2013 stands at 66\%, or two thirds). As if to compensate, Harry's use

4. Figures have been rounded up or down to the nearest whole number. 
Table 2. Synoptic view of Harry and Voldemort's epistemic dialogic positions in Harry Potter and the Chamber of Secrets, Chapter 17

\begin{tabular}{lcc}
\hline & Harry & Voldemort \\
\hline Known & 50 & 208 \\
Unknown & 20 & 6 \\
Believed & 8 & 20 \\
Vocative & 4 & 13 \\
Mirative & 2 & 0 \\
Imperative & 1 & 1 \\
Pseudo-imperative & 10 & 4 \\
Question tag $^{\mathrm{a}}$ & 1 & 0 \\
Rhetorical question $_{\text {Rhetorical question tag }}$ & 0 & 15 \\
TOTAL & 0 & 0 \\
\hline
\end{tabular}

a Pseudo-imperatives have the grammatical structure of an Imperative but their function is not to have an action performed, but rather to invite the hearer to perform or act in a particular way. Ascoli (1978) lists five types: (i) phatic interaction; (ii) exhortation; (iii) threat (i.e., do not do, otherwise...); (iv) instructions (semimodal imperative); (v) inclusive imperative (let's...). In the dialogue, we can identify the exhortative type of pseudo-imperative in turn 47 (Harry: Ginny VOCATIVE | don't be dead PSEUD IMP | please don't be dead PSEUD IMP), the discourse markers typical of the phatic type, e.g., turn 83 (Harry: Look PSEUD IMP | give me my wand IMPERATIVE) and turn 138 (Voldemort: Imagine PSEUD IMP | how angry I was KNOWN).

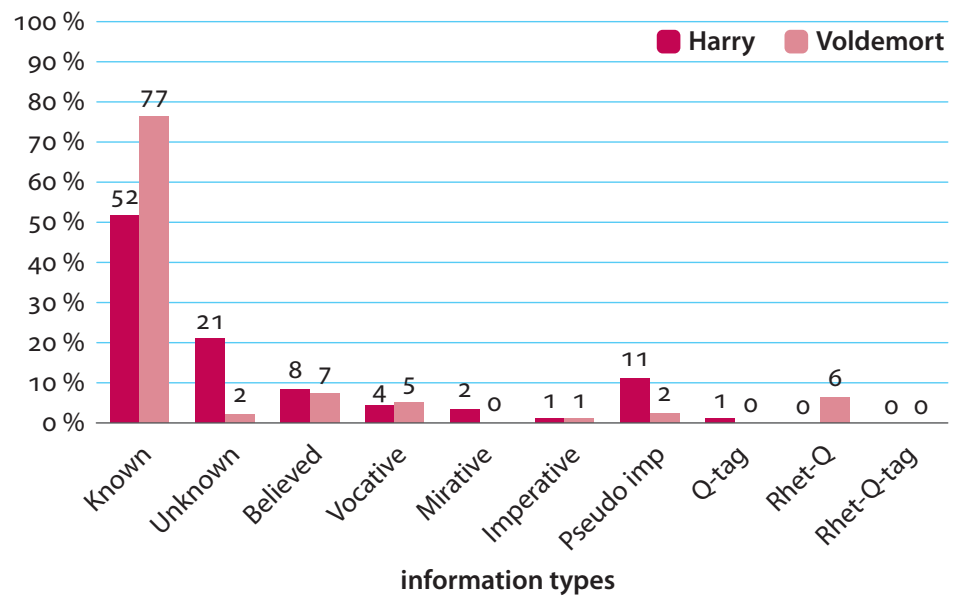

Figure 2. Percentage values for information types by character, Harry Potter and the Chamber of Secrets, Chapter 17 
of Unknowns - $21 \%$ of his output - is twice that which we would expect given the same parameters. ${ }^{5}$ The picture is clear: Voldemort is controlling the dialogue, providing the information and, as we can infer from his use of Rhetorical questions, showing contempt for Harry. Harry, on the other hand, is powerless. He has neither the knowledge nor the linguistic and magical prowess necessary to face Voldemort as an equal. This demonstration of inequality, while apparently overcome through the events that immediately follow the dialogue, characterises the Harry-Voldemort relationship throughout the remaining Harry Potter books. It is fair to say, therefore, that this dialogue represents more than a simple confrontation between the hero and his adversary: it sets the tone for the coming books, preempting the nature and content of the Harry-Voldemort confrontations to come.

\subsection{Final dialogue between Harry and Voldemort}

The second excerpt to be analysed here comes from the seventh and final book in the Harry Potter series, Harry Potter and the Deathly Hallows, Chapter 36 "The Flaw in the Plan" (Rowling 2007, 590-595). In this dialogue, the situation changes: recent events have given Harry new insight, and he now knows things that Voldemort does not.

Figures 3, 4, and 5 present three different extracts from this extended dialogue:

\begin{tabular}{llll}
\hline Turn & Speaker & Text & Tag \\
\hline 921 & HP & $\begin{array}{l}\text { You won't be able to kill any of them, ever } \\
\text { again. } \\
\end{array}$ & Don't you get it? \\
& $\begin{array}{l}\text { I was ready } \\
\text { to die } \\
\end{array}$ & RHET Q \\
& to stop you & $\mathrm{K}$ \\
& hurting these people - & $\mathrm{K}$ \\
& & $\mathrm{K}$ \\
\hline 922 & $\mathrm{~V}$ & But you did not! & $\mathrm{K}$ \\
\hline 923 & HP & - I meant to, & $\mathrm{K}$ \\
\hline & & and that's & $\mathrm{K}$ \\
& & $\mathrm{K}$
\end{tabular}

5. In other words, given the values established in our previous study (Philip et al. 2013) and the distribution of information types found in both dialogues in the present study. Taken together, these three sets of values, which differ very little from one another, provide us with a provisionary benchmark against which to compare individual speakers' clauses. This is discussed further in Section 3.3. 


\begin{tabular}{|c|c|c|c|}
\hline Turn & Speaker & Text & Tag \\
\hline & & what did it. & $\mathrm{K}$ \\
\hline & & I've done & $\mathrm{K}$ \\
\hline & & what my mother did. & $\mathrm{K}$ \\
\hline & & They're protected from you. & $\mathrm{K}$ \\
\hline & & Haven't you noticed & RHET Q \\
\hline & & how none of the spells you put on them & RHET Q \\
\hline & & are binding? & RHET Q \\
\hline & & You can't torture them. & K \\
\hline & & You can't touch them. & $\mathrm{K}$ \\
\hline & & $\begin{array}{l}\text { You don't learn from your mistakes, Riddle, do } \\
\text { you? }\end{array}$ & $\begin{array}{l}\text { RHETQTAG } \\
+ \text { VOCATIVE }\end{array}$ \\
\hline 924 & $\mathrm{~V}$ & You dare - & MIRATIVE \\
\hline \multirow[t]{9}{*}{925} & $\mathrm{HP}$ & Yes, I dare, & $\mathrm{K}$ \\
\hline & & I know things & $\mathrm{K}$ \\
\hline & & you don't know, & $\mathrm{K}$ \\
\hline & & Tom Riddle. & VOCATIVE \\
\hline & & I know lots of important things & $\mathrm{K}$ \\
\hline & & that you don't. & $\mathrm{K}$ \\
\hline & & Want & $\mathrm{U}$ \\
\hline & & to hear some, & $\mathrm{U}$ \\
\hline & & before you make another big mistake? & $\mathrm{U}$ \\
\hline
\end{tabular}

Figure 3. KUB analysis of an excerpt (Part 1) from Harry Potter and the Deathly Hallows, Chapter 36, 591

In Figure 3, we can see that the situation is turned upside down, compared with Harry Potter and the Chamber of Secrets: now Harry takes the floor, dominating the dialogue and - like Voldemort in the previous excerpt (Figure 1) - he speaks predominately from the Knowing position. He also uses an ironic Question tag and two other Rhetorical questions (one of which consists of two clauses) to mock Voldemort's ignorance compared to his own knowledge. As mentioned in the analysis of the first extract, the questions "Don't you get it?" (turn 921) and "Haven't you noticed how none of the spells you put on them are binding?" (turn 923) are not interpreted as plain questions but as Rhetorical ones. The interpretation of the question "Don't you get it?" is similar to that assigned to the question "Haven't you guessed, yet, Harry Potter?" in the first extract (cf. Figure 1, turn 101) because the critical message conveyed by the question is the corresponding declarative sentence "You don't get it" and does not correspond to an answer. An 
analogous interpretation holds for the second question "Haven't you noticed how none of the spells you put on them are binding?" (turn 923), meaning "you haven't noticed that none of the spells you put on them are binding".

The Rhetorical question tag "You don't learn from your mistakes, Riddle, do you?" (turn 923) is a little different from the usual Question tag, because rather than communicating a nuance of uncertainty, it communicates sarcasm or criticism instead. Normally, Question tags are produced from a Believing position, because the speaker asks for confirmation of an uncertainty he has regarding one of her/his suppositions. In other cases, such as in this one, we read an evaluative note into the Question tag (the sarcasm or criticism just mentioned). Therefore, the fact that Voldemort does not learn from his mistakes is communicated from a Knowing position and not from a Believing one: I know you don't learn from your mistakes (as you should).

Turn 4 "you dare" was interpreted as an expression of surprise, incredulity in Voldemort about the information given by Harry and, therefore, it was tagged as Mirative: Voldemort did not expect Harry to mock him and so he is shocked and angered: there is a passage from Unknown to Known, characterized by surprise and incredulity.

\begin{tabular}{llll}
\hline Turn & Speaker & Text & Tag \\
\hline 945 & HP & $\mathrm{K}$ \\
& but you didn't have him killed. & $\mathrm{K}$ \\
& He chose his own manner & $\mathrm{K}$ \\
& of dying, & $\mathrm{K}$ \\
& chose it & $\mathrm{K}$ \\
& months before he died, & $\mathrm{K}$ \\
& arranged the whole thing & $\mathrm{K}$ \\
& with the man you thought & $\mathrm{K}$ \\
& was your servant. & $\mathrm{K}$ \\
\hline 946 & What childish dream is this? & $\mathrm{MIRATIVE}$ \\
\hline V & Severus Snape wasn't yours. & $\mathrm{K}$ \\
& Snape was Dumbledore's. & $\mathrm{K}$ \\
& Dumbledore's from the moment you started & $\mathrm{K}$ \\
& hunting down my mother. & $\mathrm{K}$ \\
& And you never realized it, & $\mathrm{K}$ \\
& because of the thing you can't understand. & $\mathrm{K}$ \\
& You never saw & RHET QTAG
\end{tabular}




\begin{tabular}{lll}
\hline Turn & Speaker & Tag \\
\hline & $\begin{array}{l}\text { Snape cast a Patronus, did you, } \\
\text { Riddle? }\end{array}$ & RHET QTAG \\
& $\begin{array}{l}\text { Snape's Patronus was a doe, the same as my } \\
\text { mother's, }\end{array}$ & $\mathrm{K}$ \\
& because he loved her for nearly all of his life, \\
from the time when they were children. & $\mathrm{K}$ \\
& You should have realized, & $\mathrm{K}$ \\
he asked you & B \\
to spare her life, didn't he? & QTAG \\
\hline
\end{tabular}

Figure 4. KUB analysis of an excerpt (Part 2) from Harry Potter and the Deathly Hallows, Chapter 36, 593

Turn 946 (Figure 4), "what childish dream is this?” is also considered as a Mirative, for the same aforementioned reasons: the information given by Harry is totally unexpected for Voldemort and judged negatively: Voldemort does not believe the information he has just heard, he considers it implausible, and so defines it "a childish dream", nothing more than fantasy. In Harry's speech, the Knowing position prevails. His question "You never saw Snape cast a Patronus, did you, Riddle?"(turn 947) is interpreted as a Rhetorical question tag in the sense that the message conveyed is declarative and implies criticism. We tagged "You should have realized" as coming from a Believing position because of the conditional "should". At the end of turn 947 Harry's two-clause Question tag is different from the above Rhetorical question tag because it expresses uncertainty and he is asking for confirmation: it is a proper Question tag from a Believing position.

\begin{tabular}{llll}
\hline Turn & Speaker & Text & Tag \\
\hline 964 & HP & That wand still isn't working properly for you, & $\mathrm{K}$ \\
& & because you murdered the wrong person. \\
& & Severus Snape was never the true master of the Elder \\
& Wand. & $\mathrm{K}$ \\
& & \\
\hline 965 & $\mathrm{~V}$ & He never defeated Dumbledore. & $\mathrm{K}$ \\
\hline 966 & HP & Aren't you listening? & $\mathrm{K}$ \\
& & Snape never beat Dumbledore! & RHET Q \\
& & Dumbledore's death was planned between them! & $\mathrm{K}$ \\
& & Dumbledore intended & $\mathrm{K}$ \\
& & to die undefeated, the wand's last true master! & $\mathrm{K}$
\end{tabular}




\begin{tabular}{|c|c|c|c|}
\hline & & If all had gone as planned, & $\mathrm{B}$ \\
\hline & & the wand's power would have died with him, & $\mathrm{B}$ \\
\hline & & because it had never been won from him! & $\mathrm{K}$ \\
\hline 967 & $\mathrm{~V}$ & But then, Potter, & VOCATIVE \\
\hline & & Dumbledore as good as gave me the wand! & $\mathrm{B}$ \\
\hline & & I stole the wand from its last master's tomb! & $\mathrm{K}$ \\
\hline & & I removed it against its last master's wishes! & $\mathrm{K}$ \\
\hline & & Its power is mine! & $\mathrm{K}$ \\
\hline 968 & $\mathrm{HP}$ & You still don't get it, Riddle, do you? & $\begin{array}{l}\text { RHETQTAG + } \\
\text { VOCATIVE }\end{array}$ \\
\hline & & Possessing the wand & $\mathrm{K}$ \\
\hline & & isn't enough! & $\mathrm{K}$ \\
\hline & & Holding it, & $\mathrm{K}$ \\
\hline & & using it, & $\mathrm{K}$ \\
\hline & & doesn't make it really yours. & $\mathrm{K}$ \\
\hline & & Didn't you listen to Ollivander? & RHET Q \\
\hline & & The wand chooses the wizard ... & *-CIT \\
\hline & & the Elder Wand recognized a new master & $\mathrm{K}$ \\
\hline & & before Dumbledore died, & $\mathrm{K}$ \\
\hline & & someone who never even laid a hand on it. & $\mathrm{K}$ \\
\hline & & The new master removed the wand from Dumbledore & K \\
\hline & & against his will, & K \\
\hline & & never realizing exactly & K \\
\hline & & what he had done, & $\mathrm{K}$ \\
\hline & & $\begin{array}{l}\text { or that the world's most dangerous wand had given him } \\
\text { its allegiance ... }\end{array}$ & K \\
\hline
\end{tabular}

Figure 5. KUB analysis of an excerpt (Part 3) from Harry Potter and the Deathly Hallows, Chapter 36, 594-595

In the extract in Figure 5, the questions “Aren't you listening?" (turn 966), "Didn't you listen to Ollivander?" (turn 968) and the question tag "You still don't get it, Riddle, do you?" (turn 968) have been interpreted as Rhetorical and their meaning corresponds to the following declarative sentences respectively: you aren't listening, you didn't listen to Ollivander, you still don't get it. This dominance of Rhetorical questions pronounced by Harry is a clear indication of how the relationship between the two characters has reversed compared with the second book. Now it is Harry who demonstrates a kind of triumphalism in possessing knowledge that Voldemort does not share. As for the Believed in turn 967, Voldemort is 
following the hypothesis made by Harry in turn 966 ("If all had gone as planned, the wand's power would have died with him, because it had never been won from him!") and makes a further hypothesis based on that.

The same predominance of Harry's Knowns can be found in the whole of Chapter 7 (Table 3):

Table 3. Synopsis of Harry and Voldemort's epistemic dialogic positions in Harry Potter and the Deathly Hallows, Chapter 36

\begin{tabular}{lcc}
\hline & Harry & Voldemort \\
\hline Known & 109 & 61 \\
Unknown & 9 & 6 \\
Believed & 9 & 20 \\
Vocative & 4 & 8 \\
Mirative & 0 & 5 \\
Imperative & 6 & 1 \\
Pseudo imperative & 0 & 0 \\
Question tag & 1 & 1 \\
Rhetorical question & 14 & 0 \\
Rhetorical question tag & 3 & 0 \\
\hline TOTAL & 155 & 102 \\
\hline
\end{tabular}

As was the case in Table 2 above (Section 3.1), the raw figures give a good impression of the proportions of the information types in the utterances of each of the characters, but percentage figures make this relationship clearer. Figure 6 therefore shows the same data converted into percentage values, making it easier to see at a glance which information types can be best associated with each character at this late point in the saga. ${ }^{6}$

The data in Figure 6 show a much more balanced picture than the equivalent data for Chapter 2 (Figure 2, above). In particular, the yawning gap between the characters' Knowns and Unknowns has narrowed markedly, with Harry's Knowns now exceeding the benchmark figure of two-thirds of total output, and his Unknowns now equal to Voldemort's (both are below the benchmark of approximately one in ten clauses, cf. footnote 6). Adding to these indicators of knowledge is the significant number of Rhetorical questions (9\%; Rhetorical questions are normally grouped as "other" because their occurrence is usually of negligible importance), characteristic of an authoritative voice, and the speech of the more powerful interlocutor in any asymmetric conversation. Harry, it seems, is gaining power.

If Harry is stronger, we can suppose that Voldemort is weakening his hold over him, if not weakening physically or in terms of magical prowess. In this final

6. As before, these have been rounded up or down to the nearest whole number. 


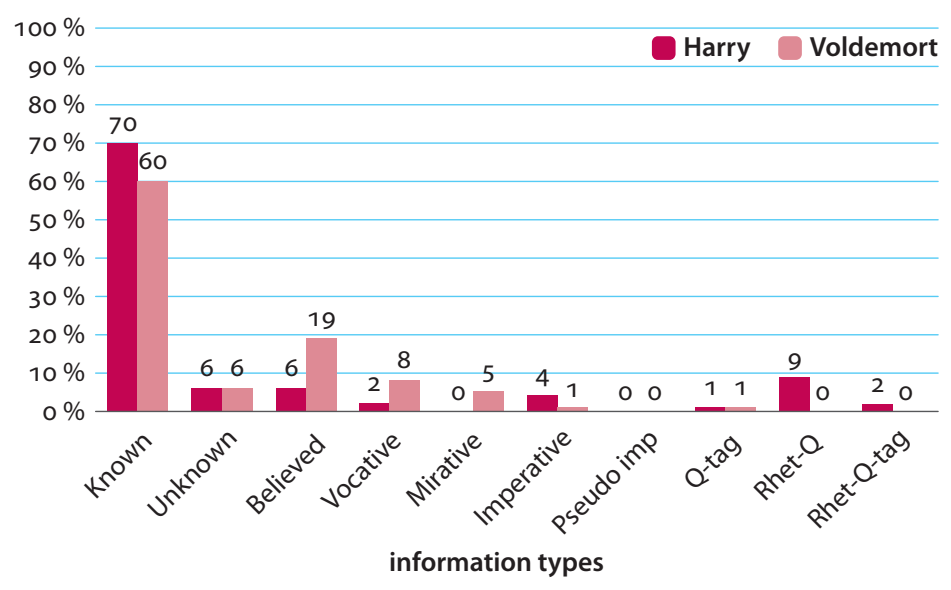

Figure 6. Percentage values for information types by character, Harry Potter and the Deathly Hallows, Chapter 36

dialogue, Voldemort's Knowns slip slightly below our benchmark figure of $65 \%$, but not enough to merit comment. What does deserve a mention is that he utters twice as many Believed clauses as Harry does, the proportion of his Believed clauses now double the benchmark figure of $10 \%$. He is also the originator of all the Miratives. Viewing these characteristics together, we can notice that Voldemort is operating primarily from a Believed standpoint. He no longer is the fount of all knowledge and is forced to resort to hypothetical reasoning in order to combat Harry Potter.

\subsection{Discussion of shifting power dynamics in the first and final Harry- Voldemort dialogues}

In this section we compare the differences between the two dialogues analysed, as a means of offering an overview of how the relationship between Harry Potter and his nemesis, Voldemort, changes in the seven-book saga. Figure 7 summarises the proportions of each information type present within each of the two dialogues, providing a reference point against which to compare and contrast the individual characters' outputs.

Figures $8 \mathrm{a}$ and $8 \mathrm{~b}$, in contrast, show another way of viewing the data, which forms part of the discussion to follow. Rather than looking at the raw figures and percentages head-on, character by character, here we look at the data sideways to calculate what proportion of each information type is uttered by which character. ${ }^{7}$

7. While we acknowledge that it is not normally acceptable to generate percentages from figures less than 100, the graphs in Figures 8a and 8b make it possible to appreciate the balance of distribution of information type per speaker. The percentages are calculated by dividing the number 


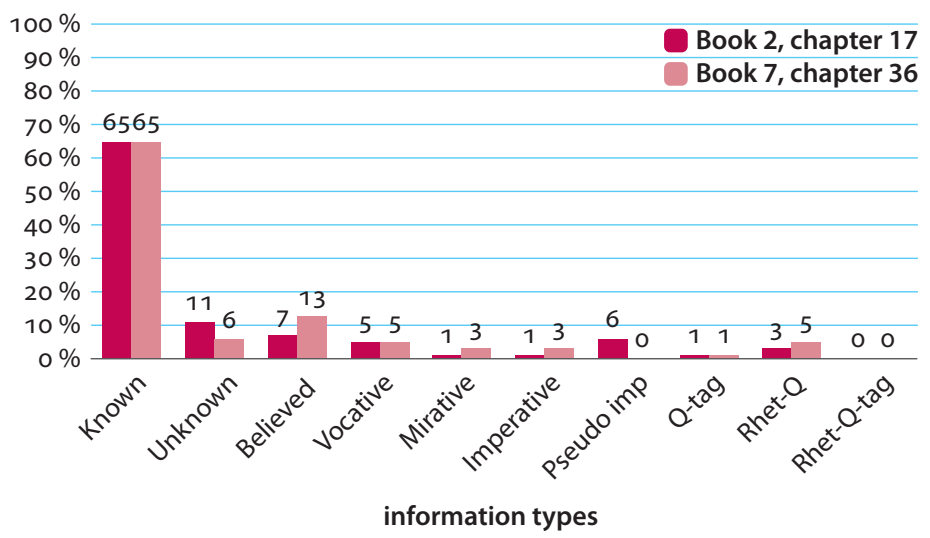

Figure 7. Comparison of proportions of each information type in the two dialogues

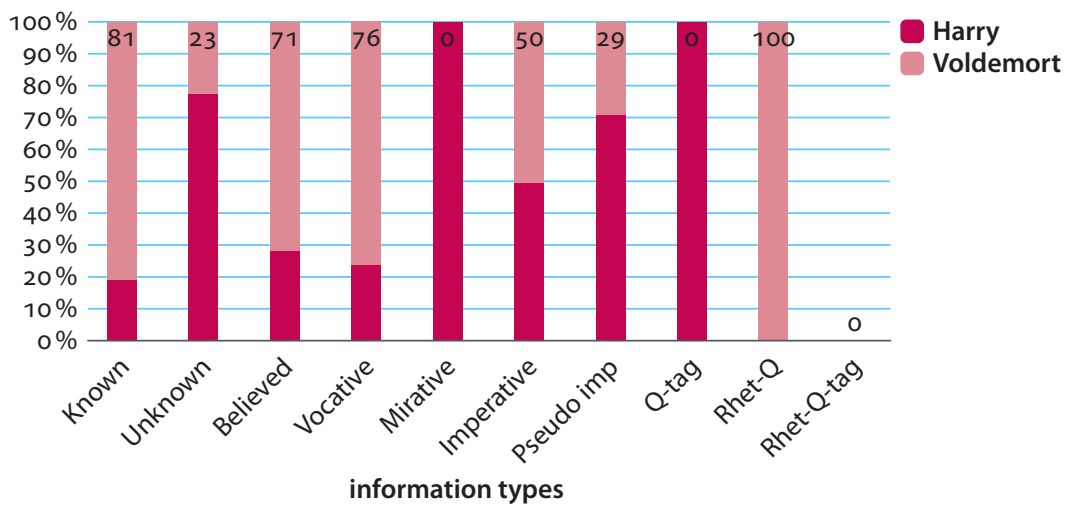

Figure 8a. Proportions of each information type as uttered by each speaker, Harry Potter and the Chamber of Secrets, Chapter 17

In previous research, we reported that in the extended section of dialogue analysed (from Book 7, Chapter 10), the overall proportions of Known, Unknown, and Believed clauses, independent of speaker, were $66 \%, 10 \%$, and $11 \%$ respectively (Philip et al. 2013, 22-26). In other words, Known clauses accounted for two thirds of all the clauses uttered, whereas Unknown and Believed clauses accounted for approximately one in ten respectively. While not identical - and there is no reason why we should expect different dialogues to maintain their information

\footnotetext{
of clauses uttered by each speaker for each information type by the sum of the clauses uttered for each information type. Therefore Harry has $100 \%$ of the Mirative weight in the Book 2 dialogue (Figure 8a) even though he utters only two Mirative clauses (cf. Table 2). There are no Rhetorical question tags in the Book 2 dialogue, nor Pseudo-imperatives in the Book 7 dialogue, hence the apparently absent data columns.
} 


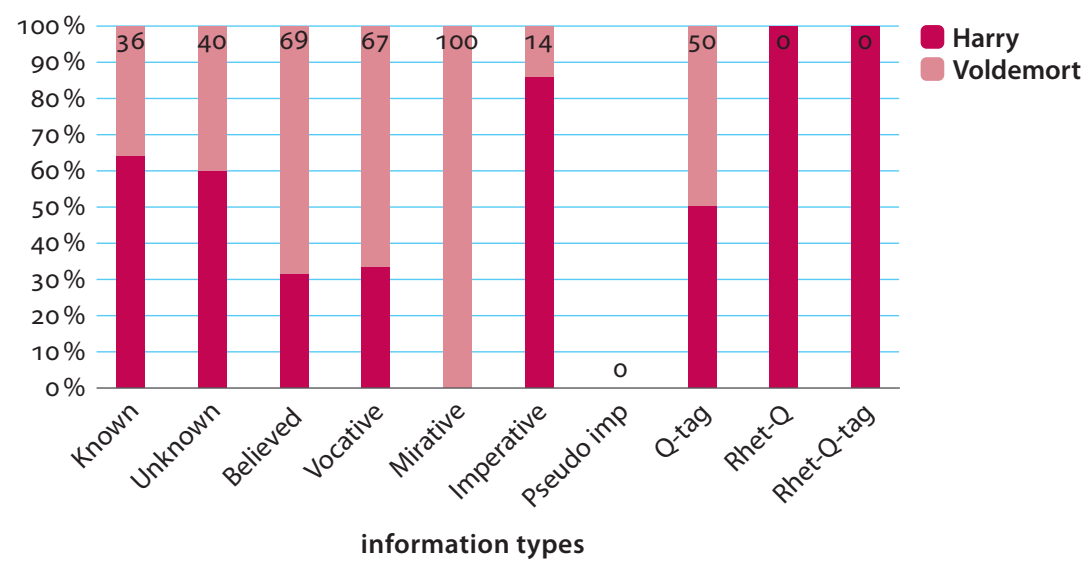

Figure 8 b. Proportions of each information type as uttered by each speaker, Harry Potter and the Deathly Hallows, Chapter 36

values at different points in a long work - the figures for the dialogues analysed in the present contribution tally fairly well with this earlier finding, particularly with regard to the presence of Known, which remains constant at two thirds of all clauses uttered (65\% in both excerpts analysed, Figure 7). Unknown and Believed together also account for approximately one in five clauses, but there are subtle changes here which are worthy of further investigation in relation to other dialogues. In Book 2, Chapter 17, there are more Unknown than Believed (11\% Unknown; 7\% Believed); in Book 7, Chapter 36, the position is reversed, with more Believed (13\%) than Unknown (6\%), cf. Figure 7. The following paragraphs will discuss these proportions in relation to characterization and plot, in an attempt to unite quantitative facts with qualitative aspects of literary interpretation.

Known clauses, it seems, are the bread and butter of dialogic communication in the Harry Potter novels. Yet the constant proportion of Known with respect to other information types (Figure 7) belies interesting dynamics in the characterization and plot progression. In Section 3.1 we observed that Voldemort not only uttered Known as $77 \%$ of all his clauses, but that he also uttered nearly three times as many clauses overall as compared to Harry (267 clauses, opposed to 96). Proportionally, then, Voldemort's Knowns account for $81 \%$ of all the Known uttered in the first dialogue (Figure 8a). At the end of the saga, the tables are turned on Voldemort. Again, the overall proportion of Knowns is $65 \%$, but Voldemort's Knowns (totalling 61 in number, or $60 \%$ of his own output in this dialogue, Figure 7) account for only $36 \%$ of the total Known in the dialogue (Figure $8 b$ ). This signals a significant shift in power between the two characters, as the once-powerful Dark Lord is left 
impotent in the wake of Harry's gesture of self-sacrifice. ${ }^{8,9}$ Voldemort utterly fails to comprehend the implications of Harry's actions because - as the reader has learned over the course of the books - "If there is one thing Voldemort cannot understand, it is love. [...] To have been loved so deeply, even though the person who loved us is gone, will give us some protection forever." (Rowling 1997, 216).

The varying proportions of Unknown and Believed clauses should be viewed in the light of this major shift in dynamics, and not as stand-alone phenomena. Once again, the raw figures and general percentages mask somewhat the underlying goings-on in the narrative. At the start of the saga, Harry is young, inexperienced and wholly ignorant of the circumstances that caused him to be orphaned in infancy and successively venerated as a celebrity within the magical community. Voldemort, apparently annihilated when his killing spell aimed at baby Harry backfired, is regaining power. Unable as yet to take on independent human form, he is strong enough to possess the minds and bodies of others. In the second book, Voldemort appears in a ghostly form of his schoolboy self, Tom Marvolo Riddle (see Section 4.2), but his words are those of the adult black wizard.

The excerpt from this dialogue shown in Figure 1 above is indicative of the conversation dynamics of the extended dialogue. Voldemort dominates in terms of number of clauses and length of conversation turn, and utters $81 \%$ of the Known clauses (Figure 8a). It is only to be expected, therefore, that Harry should act as a counterbalance, generating Unknowns. This he does, in almost perfect symmetry (Figure $8 \mathrm{a}$ ): $73 \%$ of the Unknown clauses uttered are his. ${ }^{10}$ These elements signal Harry's powerlessness against the superior knowledge and abilities of his adversary, and reinforce the reader's perception that the odds are firmly stacked against Harry.

This situation does eventually change. Five years on, in the final dialogue, Harry is no longer a weak schoolboy, ignorant of his past and that of his parents

8. It should be pointed out that the shift is not a gradual one, occurring over the course of the saga, but rather one of several features in Book 7 which signal major shifts in the narrative thread and in characterisation, particularly from Chapter 33 onwards (Philip 2011).

9. Harry accepts that he must die so that the part of Voldemort's soul that is lodged within him will also cease to exist. In accepting his fate, Harry activates a sort of magical protection - the very same as that which his own mother had bestowed on him - which means that Voldemort can no longer do harm to others. Part of this is explained in the excerpt in Figure 3 ("You won't be able to kill any of them, ever again. Don't you get it? I was ready to die to stop you hurting these people - [...] I've done what my mother did. They're protected from you.")

10. In our previous research, Harry was found to be responsible for $51 \%$ of the Unknown clauses uttered (Philip et al. 2013:23-24). Various sources have discussed Harry's ignorance as an essential narrative device because it allows the reader to uncover the facts together with the protagonist rather than through the narrator's voice (see especially Granger 2007, and Gupta 2009 on this point). 
and their contemporaries. In the final confrontation of Harry and Voldemort, the two meet on rather different terms. Harry has acquired knowledge and understanding which now surpass Voldemort's knowledge, blinded as it is by hatred and evil; and this is reflected in Harry's vastly increased use of Known clauses, previously $19 \%$ of all Knowns (Figure 8a), now $64 \%$ (Figure $8 b$ ). It is also reflected in his use of Unknown clauses, now proportionally reduced ( 9 are Harry's, 6 Voldemort's $-a^{2 / 3}-1 / 3$ proportion compared to the $3 / 4-1 / 4$ previously). This change is in fact more significant for Voldemort than it is for Harry, particularly if we consider that, overall, the proportion of Unknown clauses in the second dialogue is half that of the first (6\% in Book 2, 11\% in Book 7, cf. Figure 7) and that now all the Miratives (five in number) in the dialogue are uttered by him. ${ }^{11}$ Not only is Voldemort's ignorance reinforced when he utters these indicators of surprise: crucially, he reveals his weakness.

The final indicator that by the end of Book 7 Harry has now gained the upper hand is found in the use of Imperatives. These are low-frequency items, making it spurious to talk of percentages, but the raw figures speak for themselves. In Book 2 , each character uttered one Imperative each; in the final dialogue (Figure $8 b$ ), Harry increases his number sixfold, while Voldemort remains unchanged - he is now the one being ordered around, the one expected to obey. The consequence of Voldemort's ignorance, surprise and his taking orders is, inevitably, that his previously-held power, based on terror, torture, and murder, slips through his fingers.

A final word needs to be said about the proportions of Believed clauses in the two dialogues. While each character uses the same proportion of Believed clauses relative to his own speech output (Figure $8 \mathrm{a}, 8 \mathrm{~b}$ ), the proportion of Believed clauses in the final dialogue is almost twice that of the first one (7\% in Book 2, 13\% in Book 7, cf. Figure 7). ${ }^{12}$ We have already noted that the Unknown clauses halve over the course of the series - and this might be expected as the series draws to a close and Unknown matters are resolved (Philip et al. 2013, 14; 36-37). The Believed clauses increase not because new information needs to be supplied, but so that mistaken points of view and hypotheses can be corrected. The most important of these is that the all-powerful Elder Wand now in Voldemort's possession was rendered powerless as a result of the complex events surrounding its previous owner's (Dumbledore's) death. Harry knows this and reveals it to Voldemort who is incredulous and still certain of his own victory to the very end, when he discovers to his mortal cost that Harry did in fact know more than him.

11. Compare to Book 2, where all the Miratives (only two) were Harry's.

12. Harry's Believed clauses account for $29 \%$ of the total in the first dialogue, and $31 \%$ in the second. Voldemort's Believed clauses are respectively $71 \%$ and $69 \%$. 


\section{Dialogue and characterisation}

The dynamics of Known, Unknown and Believed in dialogues featuring Harry are fundamental to the reader's understanding of the story. The books are written from a third-person omniscient point of view, but feature strongly a narrative effect which Granger $(2007,15)$ calls "narrative misdirection". While we have the impression of being told the story by the narrator, we view all events through Harry's eyes. We know what Harry sees, and knows, and we also know how he feels, but our only experience as readers of events and of other characters is through Harry. His blind spots are our own, and it is only as information is revealed directly to him that we too learn what is going on. So rather than a third-person omniscient narration, we have "third-person limited-omniscient" narration (Granger, 2008, 4, our emphasis).

The graphic in Figure 9 illustrates just how little Harry knows at the outset. The darker circle, that is the smallest one, the point of intersection of all the circles, shows what Harry Knows in the first book, Harry Potter and the Philosopher's Stone (Rowling 1997), and becomes bigger as the series progresses: he discovers more and more information from the other characters. While presented as a classic struggle between Good and Evil, the saga is ultimately a search for knowledge which straddles the domains of the Known and the Unknown. In the end, it is the person who knows the most who will emerge as the victor.

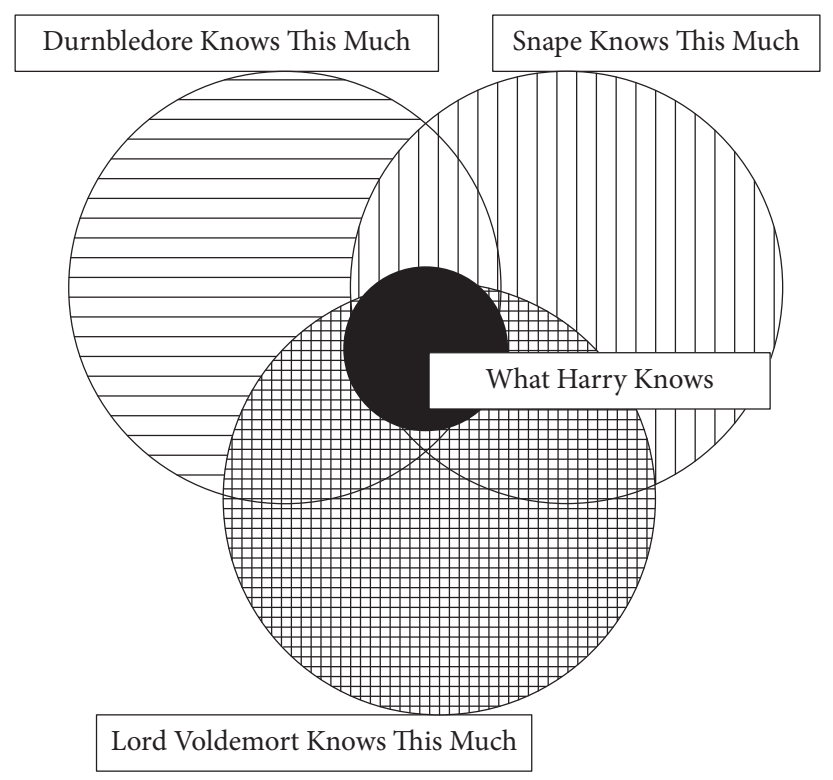

Figure 9. What Harry, Dumbledore, Snape, Lord Voldemort know at the beginning of the saga (Granger 2007, 17) 


\subsection{Harry Potter}

Our first introduction to Harry Potter is as a pre-pubescent boy living with his grotesquely normal aunt and uncle, and his spoiled cousin. He is an archetypal weakling: a small, skinny orphan boy, starved of affection and bullied by his adoptive family. From the moment he discovers that he is a wizard and begins his adventures at Hogwarts School of Witchcraft and Wizardry he blossoms. He makes strong friendships (and a few enemies), gets up to all sorts of antics, and proves himself a good sportsman and team-player. These are all characteristics of the hero in British boarding-school novels, a genre which Harry Potter can be assigned to (Mynott 1999, Smith 2003, Steege 2002).

When he encounters the magical world for the first time, Harry becomes an overnight celebrity - overnight from the "third-person limited-omniscient" viewpoint, at any rate. He discovers that he is the only person alive to have survived a killing curse by the most powerful and dreaded of all dark wizards, Lord Voldemort, and discovers that the lightning shaped scar on his forehead is a curse scar, a remnant from that encounter in which both his parents were killed. He is The Boy Who Lived, a hero figure in the magical world, instantly recognisable by all by virtue of his scar.

This is not the place to embark on a synopsis of the plots of the seven novels. Suffice it to say that as Harry grows up and encounters (and survives) ever-more challenging encounters with the Dark Lord, he earns the hero status that, at first, he was automatically assigned by others. As he starts to reconstruct his identity from the fragments of information that friends and acquaintances provide him with about his own past (and about that of his parents and their contemporaries), he carves out his own path and destiny, in the spirit of a Bildungsroman (Pharr 2002, 65-66). Harry grows up, not just literally but also morally, and in the end understands that there is a very fine line between Good and Evil, and that the individual is free to make a choice between the two - but must make that choice.

Harry's is a journey from Unknown to Known (Steveker 2011); an insecure, ignorant child eventually becomes a self-aware young adult with enough knowledge to complete his ultimate goal - to vanquish Voldemort and thus to avenge the deaths of his loved ones and to restore the world to Good. For KUB theory, this would suggest that as the story progresses, Harry's worldview should shift away from the realm of the Unknown, and consolidate in the world of the Known. This is indeed what has emerged from the data presented in this study, although analysis of intervening dialogues is necessary to understand if the shift is abrupt - as Philip (2011) argues — or if it takes place in a more gradual manner. 


\subsection{Lord Voldemort}

Rowling makes use of a centuries-old strategy in having her magical characters fear the name of the dark wizard, Voldemort. Fear of the name equalling fear of the thing itself is a belief found in many cultures, primitive or otherwise, and is an aspect of the magical power of words in general, and proper names in particular (see Crystal 1987, 8-9). Naming Voldemort is taboo, as Harry discovers in his naivety. The magical community refer to him as "He Who Must Not Be Named", or, colloquially "You Know Who". The linguistic strategy of distancing Voldemort by banning his name gives people a sense of immunity and protection, yet what euphemism does in this case is to promote an aura of mystery and fear, which is further fuelled by rumour and speculation. Voldemort makes few appearances in the novels, but is omnipresent by name, and this exerts a consistent influence on the psyche of the community (Bhattacharya 2012,3-4).

The magical value of names does not end with euphemism. The character starts out in life with the name Tom Marvolo Riddle. Lord Voldemort is an anagram of this name, chosen by the character to rid himself of all traces of his family background. Both these names are emblematic, as are so many character names in the Harry Potter series (Algeo 2001; Fernandes 2006). Riddle is an enigma, both as a man and as a problem for Harry to solve; Voldemort (French: vol de mort, or 'flight from [also: steal from] death') is the man who has wrenched his own soul from his body to preserve it, in fragments, and thus conquer death. ${ }^{13}$

It is in the first dialogue between Harry Potter and Voldemort, analysed in Section 3.1 above, that the dual identity of Tom Riddle and Voldemort is revealed to Harry (and to readers). It is the first of many revelations that Voldemort is to make in dialogue with Harry: Voldemort's Known clauses are met with surprise and incredulity (Miratives), or with questions (Unknown clauses) on the part of Harry. As was discussed in Section 3.3, the power balance is firmly in Voldemort's favour. Harry doesn't stand a chance, and, frankly, it is only thanks to his two friends and the trio's combined abilities that he ever survives each successive book's trial.

That Voldemort stands firmly in a Knowing position for most of the series is essential for plot development: the nemesis must always know more in order to stay ahead. It is only in the final two books that Harry, initially with Dumbledore's assistance, starts hunting down his enemy (Rowling 2005, 2007). Using all the knowledge available to them, they start to attack not the wizard himself, but all the horcruxes where he has concealed fragments of his soul in order to preserve them outside his human body. Voldemort's certainty of his own superior intelligence

13. For more on “Tom Marvolo Riddle” / "Lord Voldemort”, see Anastasaki 2007, 3-4. 
and magical prowess reaches a crisis when he realises that he is being hunted. $\mathrm{He}$ thought that he alone knew about his secret horcruxes (Known becomes reclassified as mistaken Belief), and when he realises that the nature of his invincibility has been discovered and is being systematically attacked, decides to take action to acquire the Elder Wand. As can be read in the conversation excerpts in Figures 3, 4 , and 5, Voldemort's certainty that in possessing the Elder Wand he would once again be invincible is undermined, initially when it fails to prove as powerful as expected (Known turns to doubt, mistaken Belief), and successively, when Harry reveals that mere possession is not enough, but that the Wand had to be won in a wizard's duel and would only function for its rightful master (Belief turns to Mirative, offering evidence of Unknown). As Harry's character grows and moves steadily into the Known domain, Voldemort finds the certain ground disappear beneath his feet. In the end, Knowledge triumphs over all, and Voldemort pays a high price for his presumption.

\section{Conclusion}

This study set out to examine the first and final dialogues between Harry Potter and Lord Voldemort in Rowling's seven-book Harry Potter series, using the framework provided by KUB analysis (Bongelli et al. 2013; Riccioni et al. 2013; Zuczkowski et al. forthcoming), to expand upon an earlier study which indicated a strong correlation between characterisation and the epistemic stance of characters measured by the Known, Unknown and Believed clauses that they produce in their dialogical interaction (Philip et al. 2013). Further studies on intermediate points in the books are also under way, but this "before and after" snapshot provides us with an interesting reference point to test the usefulness of KUB theory within a literary analysis.

The first dialogue between characters in any novel is significant because it sets the tone for what is to come. The characters position themselves in relation to each other; the reader discovers whether the relationship is likely to be one of friendship or enmity, productive, unproductive, or a mere pastime. In this dialogue (Book 2, Chapter 17) we are left with no doubt in our mind: Harry is our hero, but his chances of winning against this adversary are decidedly slim. Voldemort, even here in the guise of Tom Riddle, possesses power, knowledge, and a complete disregard for the wellbeing of others - which increases his strength further, since he has no need for friends and thinks nothing of discarding lives to save his own skin. Voldemort is not fully present in physical form, and takes on an almost god-like omnipresence. He can invade other people's thoughts, possess their bodies, act through them unharmed and is invincible. Harry is a twelve-year-old schoolboy 
with only a very hazy idea of why he is involved at all in this story. He learns too late that the diary which wrote back to him was a black magic artefact, he learns too late that his friend's sister is possessed and responsible for heinous acts of violence, he learns too late that Tom Riddle is really Voldemort. Harry Potter always learns too late. He will always be the underdog.

The KUB analysis supports this literary interpretation: Voldemort already Knows. He knows what he wants Harry to do for him (Imperatives) and he knows how the story will unfold (which we, the readers, viewing events from Harry's limited omniscient viewpoint, do not and cannot know). Harry does not know, and is surprised when information is revealed to him. In other words he does not have his existing Beliefs confirmed as Knowns - he does not Know.

A great deal of action and dialogue takes place before we reach the final Harry-Voldemort dialogue in Book 7, Chapter 36. Harry is five years older, now a young adult, and has acquired a degree of emotional maturity, awareness, and knowledge. Voldemort is now in full human form, a truly dreadful being: even his own sycophants quail in the fear that a misplaced word or gesture will earn them their death.

When they confront each other for the last time, the situation is peculiar. For the first time in the novels, it is Harry's appearance that comes as a surprise (Voldemort believed him dead, having delivered the killing curse himself). This event sets the scene. Voldemort's Known (that Harry is dead) reverts to Belief (he thought that Harry was dead, but he was wrong). Many more of Voldemort's certainties follow this pattern over the course of this final dialogue. Harry takes the floor as fount of Knowledge, and his own uncertainties have been dispelled. Voldemort's Knowledge is revealed to be, at best, mistaken Belief. The Dark Lord's power-hold loosens and, in the end, his dogged conviction that the Elder Wand would guarantee his supremacy is paid for with his life. He delivers a killing curse to Harry; Harry delivers his signature disarming curse, Expelliarmus! The spells meet mid-air and, since the Elder Wand cannot cast a spell against its true master, Voldemort's killing curse rebounds and hits him square in the chest. He falls, uncomprehending. Known collapses into Unknown, and Voldemort is no more.

Voldemort fell backwards, arms splayed, the slit pupils of the scarlet eyes rolling upwards. Tom Riddle hit the floor with a mundane finality, his body feeble and shrunken, the white hands empty, the snake-like face vacant and unknowing. Voldemort was dead.

(Rowling 2007, 596) 


\section{References}

Algeo, John. 2001. "A Fancy for the Fantastic: Reflections on Names in Fantasy Literature." Names: A Journal of Onomastics 49 (4): 248-253. DOI: 10.1179/nam.2001.49.4.248

Anastasaki, Elena. 2007. "Harry Potter through the Looking-Glass: Wordplay and Language in the Works of Lewis Carroll and J. K. Rowling." The Carrollian - The Lewis Carroll Journal 19: 19-31.

Ascoli, Christina. 1978. "Some Pseudo-imperatives and their Communicative Function in English." Folia Linguistica 12 (3-4): 405-416. DOI: 10.1515/flin.1978.12.3-4.405

Bhattacharya, Saradindu. 2012. "Demons and Demos: Voldemort, Democracy and Celebrity Culture.” The Looking Glass: New Perspectives on Children's Literature 16 (1): 1-9. http:// www.the-looking-glass.net/index.php/tlg/article/view/279.

Blankenship, Kevin L., and Traci Y. Craig. 2006. "Rhetorical Question Use and Resistance to Persuasion: An Attitude Strength Analysis." Journal of Language \& Social Psychology 25 (2): 111-128. DOI: 10.1177/0261927X06286380

Blankenship, Kevin L., and Traci Y. Craig. 2007a. "Powerless Language Markers and the Correspondence Bias Attitude Confidence Mediates the Effects of Tag Questions on Attitude Attributions." Journal of Language \& Social Psychology 26 (1): 28-47.

DOI: 10.1177/0261927X06296470

Blankenship, Kevin L., and Traci Y. Craig. 2007b. "Language and Persuasion: Tag Questions as Powerless Speech or as Interpreted in Context." Journal of Experimental Social Psychology 43 (1): 112-118. DOI: 10.1016/j.jesp.2005.12.012

Bongelli, Ramona, Ilaria Riccioni, and Andrzej Zuczkowski. 2013. "Certain-Uncertain, TrueFalse, Good-Evil in Italian Political Speeches." In Multimodal communication in Political Speech. Shaping minds and Social and Social Action, ed. by Isabella Poggi, Francesca D’Errico, Laura Vincze, and Alessandro Vinciarelli, 164-180. Berlin: Springer.

DOI: 10.1007/978-3-642-41545-6_13

Cameron, Deborah, Fiona McAliden, and Kathy O'Leary. 1989. “Lakoff in Context: The Social and Linguistic Functions of Tag Questions." In Women in their Speech Communities: New Perspectives on Language and Sex, ed. by Jennifer Coates, and Deborah Cameron, 74-93. London: Longman.

Cheng, Karen Kow Yip. 1995. “It is a Tag Question, Isn't it?” The English Teacher 24: 1-12. http:// www.melta.org.my/ET/1995/main5.html

Crystal, David. 1987. The Cambridge Encyclopedia of Language. Cambridge: Cambridge University Press.

DeLancey, Scott. 1997. "Mirativity: The Grammatical Marking of Unexpected Information." Linguistic Typology 1: 33-52. DOI: 10.1515/lity.1997.1.1.33

DeLancey, Scott. 2001. “The Mirative and Evidentiality." Journal of Pragmatics 33: 369-382. DOI: $10.1016 / \mathrm{S} 0378-2166(01) 80001-1$

Fernandes, Lincoln. 2006. “Translation of Names in Children's Fantasy Literature: Bringing the Young Reader into Play.” New Voices in Translation Studies 2: 44-57.

Granger, John. 2007. Unlocking Harry Potter: Five Keys for the Serious Reader. Wayne, PA: Zossima.

Granger, John. 2008. The Deathly Hallows Lectures. Allentown, PA: Zossima.

Gupta, Suman. 2009. Re-reading Harry Potter (2nd ed.). Basingstoke, UK: Palgrave MacMillan. DOI: $10.1057 / 9780230279711$ 
Han, Chung-hye. 2002. “Interpreting Interrogatives as Rhetorical Questions.” Lingua 112 (3): 201-229. DOI: 10.1016/S0024-3841(01)00044-4

Heilman, Elizabeth E. (ed). 2009. Critical Perspectives on Harry Potter. New York and London: Routledge.

Heinemann, Trine. 2008, "Questions of Accountability: Yes-no Interrogatives that are Unanswerable." Discourse Studies 10 (1): 55-71. DOI: 10.1177/1461445607085590

Heritage, John, and Geoffrey Raymond. 2005. “The Terms of Agreement: Indexing Epistemic Authority and Subordination in Talk-in-Interaction.” Social Psychology Quarterly 68 (1): 15-38. DOI: $10.1177 / 019027250506800103$

Heritage, John. 2011. “Territories of Knowledge, Territories of Experience: Emphatic Moments in Interaction." In The Morality of Knowledge in Conversation, ed. by Tanya Stivers, Lorenza Mondada, and Jakob Steensig, 159-183. Cambridge: Cambridge University Press.

DOI: $10.1017 / \mathrm{CBO} 9780511921674.008$

Heritage, John. 2012a. "Epistemics in Action: Action Formation and Territories of Knowledge." Research on Language and Social Interaction 45 (1): 1-29.

DOI: 10.1080/08351813.2012.646684

Heritage, John. 2012b. “The Epistemic Engine: Sequence Organization and Territories of Knowledge." Research on Language and Social Interaction 45 (1): 30-52.

DOI: $10.1080 / 08351813.2012 .646685$

Jinjun, Wang. 2007. "Beyond Rhetorical Questions: Assertive Questions in Everyday Interaction.” Discourse Studies 9 (3): 416-418. DOI: 10.1177/14614456070090030604

Lazard, Gilbert. 1999. “Mirativity, Evidentiality, Mediativity, or Other?” Linguistic Typology 3: 91-109. DOI: 10.1515/lity.1999.3.1.91

Lazard, Gilbert. 2001. "On the Grammaticalization of Evidentiality." Journal of Pragmatics 33 (3): 359-367. DOI: 10.1016/S0378-2166(00)00008-4

Mynott, Glen. 1999. "Harry Potter and the Public School Narrative." New Review of Children's Literature and Librarianship 5 (1): 13-27. DOI: 10.1080/13614549909510612

Peterson, Tyler. 2010. "Examining the Mirative and Nonliteral Uses of Evidentials." In Evidence from Evidentials, Working Papers in Linguistics, vol. 28, ed. by Tyler Peterson, and Uli Sauerland, 129-159. Vancouver: University of British Columbia.

Peterson, Tyler. 2013. Evidentiality and the Unprepared Mind. Paper presented at the ConSOLE XXI, January 9, Potsdam: University of Potsdam.

Pharr, Mary. 2002. "In Medias Res - Harry Potter as Hero-in-Progress." In The Ivory Tower and Harry Potter. Perspectives on a Literary Phenomenon, ed. by Lana Whited, 55-66. Columbia: University of Missouri Press.

Philip, Gill. 2011. "Key Words, Pivotal Words and Leading Words in Harry Potter." Paper read at Corpus Linguistics 2011 Birmingham, UK, 20-22 July 2011.

Philip, Gill, Ramona Bongelli, Carla Canestrari, Ilaria Riccioni, and Andrzej Zuczkowski. 2013. "Negotiating Narrative. Dialogic Dynamics of Known, Unknown and Believed in Harry Potter and the Deathly Hallows." Language and Dialogue 3 (1): 6-32.

DOI: 10.1075/ld.3.1.02phi

Riccioni, Ilaria, Ramona Bongelli, and Andrzej Zuczkowski. 2013. "The Communication of Certainty and Uncertainty in Italian Political Media Discourses." In The Pragmatics of Political Discourse, ed. by Anita Fetzer, 125-165. Amsterdam: John Benjamins.

DOI: $10.1075 /$ pbns.228.08ric

Rowling, Joanne Kathleen. 1997. Harry Potter and the Philosopher's Stone. London: Bloomsbury. 
Rowling, Joanne Kathleen. 1998. Harry Potter and the Chamber of Secrets. London: Bloomsbury. Rowling, Joanne Kathleen. 2005. Harry Potter and the Half-Blood Prince. London: Bloomsbury. Rowling, Joanne Kathleen. 2007. Harry Potter and the Deathly Hallows. London: Bloomsbury.

Smith, Karen M. 2003. "Harry Potter's Schooldays: J.K. Rowling and the British Boarding School Novel." In Reading Harry Potter: Critical Essays, ed. by Gisele Anatol, 69-88. Westport, CT: Praeger.

Steege, David K. 2002. "Harry Potter, Tom Brown, and the British School Story: Lost in Transit?" In The Ivory Tower and Harry Potter. Perspectives on a Literary Phenomenon, ed. by Lana Whited, 140-156. Columbia: University of Missouri Press.

Steveker, Lena. 2011. " 'Your Soul is Whole, and Completely Your Own, Harry': The Heroic Self in J.K. Rowling's Harry Potter Series." In Heroism in the Harry Potter Series, ed. by Katrin Berndt, and Lena Steveker, 69-84. Farnham: Ashgate.

Whited, Lana A. (ed). 2002. The Ivory Tower and Harry Potter. Perspectives on a Literary Phenomenon. Columbia: University of Missouri Press.

Zuczkowski, Andrzej, Ramona Bongelli, Laura Vincze, and Ilaria Riccioni. (2014). "Epistemic Stance: Knowing, Unknowing, Believing (KUB) Positions." In Communicating Certainty and Uncertainty in Medical, Supportive and Scientific Contexts, ed. by Andrzej Zuczkowski, Ramona Bongelli, Ilaria Riccioni, and Carla Canestrari, 115-136. Amsterdam: John Benjamins.

\section{Authors' address}

Dipartimento di Scienze della Formazione

dei Beni Culturali e del Turismo

Universita di Macerata

Piazzale Luigi Bertelli, no. 1 Contrada Vallebona, 62100

Macerata, Italy

1.dorigato@unimc.it

\section{About the authors}

Laura Dorigato holds a PhD in Psychology of Communication and Cognitive Processes at the University of Macerata, Italy, investigating the application of KUB theory in literary texts. Her other research interests include foreign language teaching with young learners and the psychological analysis of children's drawings.

Gill Philip is a researcher in English language and translation at the University of Macerata, Italy, where she teaches English language and TEFL. A corpus linguist by training, she has published widely on various aspects of phraseology, figurative language, and metaphor. Recent publications include Idioms (Routledge Linguistics Encyclopedia 2010), Colouring Meaning (Benjamins 2011), and Technology and Phrases (The Encyclopedia of Applied Linguistics, Wiley-Blackwell 2012).

Ramona Bongelli is a researcher in General Psychology at the University of Macerata, Italy, where she teaches Psychology of Communication. Her main objects of research concern the study of verbal communication, both oral (everyday talk and political discourses) and written 
(scientific and literary texts). In particular, she is interested in the analysis of the linguistic forms used by speakers/writers to convey epistemic and evidential standpoints.

Andrzej Zuczkowski is Full Professor of General Psychology at the University of Macerata, Italy, where he is Director of the Research Centre for Psychology of Communication and the $\mathrm{PhD}$ programme in Psychology of Communication and Cognitive Processes. He was trained in Gestalt psychology, linguistics, and Transactional Analysis psychotherapy. His main research topics concern the relationships between linguistic communication and mental processes. In particular, in the last years he has been studying the epistemic and evidential aspects in written and spoken corpora. 